\title{
Editorial Foreword 77.2 (May 2018)
}

\section{Our Cover}

This month's cover illustration is the main altar in the interior of the Caodai Holy See of Tây Ninh, in Southern Vietnam. The left eye painted on a celestial globe represents the ubiquitous eye (Thiên nhãn 天眼) of Master Cao Đài 高臺—aka the Jade Emperor. Ngô Văn Chiêu, a civil servant in the French colonial administration, was meditating on April 20, 1921, on the island of Phú Quốc, during which he had a vision of a left eye wide open over a sun, a moon, and the constellation of the Big Dipper. Ngô had been regularly attending spirit-writing séances (phò loan 扶鸞) in Cochin-China in a series of temples affiliated with Chinese Xiantiandao 先天道 salvationist movements. From this revelation and this network, he was encouraged to launch a new religion. See the article on the topic in this issue. Photo (C) David A. Palmer, Tây Ninh, 2012.

\section{IN THIS IsSUE}

In recent years, the Journal of Asian Studies has paid increasing attention to environmental concerns, and this trend continues with this issue's symposium on the toll that war has taken on Korea's environment from the 1590s through the middle of the twentieth century. In terms of topics and geography, the rest of the front section of the issue varies widely, as of course does the final part of it that is given over as usual to reviews of individual books and sets of related titles. Authors in fields ranging from political science and sociology to linguistics and religious studies take readers from Tibet to Thailand exploring subjects that run the gamut from food safety to comedy and from the gendered dimensions of politics to the online expressions of nationalism.

The issue opens with Hugh R. Clark's contribution to our Reflections genre: "What's the Matter with 'China'? A Critique of Teleological History." A specialist in the history of Tang and Song times, Clark focuses here on the need to break free from the idea that the "holistic empire" that China would become in recent centuries was somehow destined to take the shape and form it did. To do justice to history, he argues, we need to take seriously the "alternative paths" that could easily have been followed.

Following this comes the symposium on "War and Environment on the Korean Peninsula," organized and introduced by one of our Associate Editors, ALbERT L. PARK. The centerpieces of the symposium are three essays that zero in on different periods, but share a focus on the intersection of military conflicts and natural resources. The first of these, John S. LeE's "Postwar Pines: The Military and the Expansion of State Forests in Post-Imjin Korea, 1598-1684," draws attention to issues such as the "heightened government anxieties about deforestation and timber scarcity" triggered by the Japanese 
invasions of the Chosŏn era. The second main essay, David Fedman’s "Wartime Forestry and the 'Low Temperature Lifestyle' in Late Colonial Korea, 1937-1945," zeroes in on the "ecological implications" of the Japanese state commandeering "forest products, especially timber, firewood, and charcoal" to support its efforts to expand its empire's military. The last of the core pieces, Lisa M. BRADY's "Sowing War, Reaping Peace: United Nations Resource Development Programs in the Republic of Korea, 1950-1953," takes the story of the intersection between martial and environmental issues on the Korean peninsula up through the first major Asian conflagration to follow the defeat of the Japanese empire. Park adds a commentary titled "The Reshaping of Landscapes: Systems of Mediation, War, and Slow Violence," from his perspective as a specialist in Korean history. Closing out the forum and giving it an added comparative dimension is a second commentary, "Woods and Warfare in Korea and the World: A View from China," written by Chinese environmental historian Micah S. Muscolino.

Next comes the issue's first standalone standard research article, whose author, Yoshinori Nishizaki, is based at National University of Singapore. Titled "New Wine in an Old Bottle: Female Politicians, Family Rule, and Democratization in Thailand," its central claim is that we should see the shifting gender composition of the Thai Parliament as both injecting a novel element into the country's political structure and reinforcing the trend toward a small group of families monopolizing positions of power. The rise of a large number of women from a small set of key "political families" to influential posts constitutes "one part of the long historical process through which Thailand has lapsed increasingly into a family-based patrimonial polity since the absolute monarchy was abolished."

Following this is the issue's other essay dealing with Southeast Asia: "Occulting the Dao: Daoist Inner Alchemy, French Spiritism, and Vietnamese Colonial Modernity in Caodai Translingual Practice." In this piece, Jeremy Jammes and David A. Palmer examine a mix-and-match process in which foreign and local spiritual traditions worked together to "stimulate the emergence of new movements and textual practices," which via a combination of mimicry, inversion, and jumbling transcended "the cosmologies of both the Chinese imperium and of the European colonial regime."

Next comes "Mediated Massacre: Digital Nationalism and History Discourse on China's Web" by Florian Schneider of Leiden University. Schneider uses the case of the way the Chinese state seeks to control and "structure" online commentary on the Nanjing Massacre to shed light on how nationalist ideas are altered and reinforced in familiar and novel ways in the "information age." One reason this issue matters, according to Schneider, is that it is an example of web-based discourse that "reproduces" forms of nationalism whose hold on communities helps make "reconciliation of historical disputes in East Asia so protracted."

Closing out the front part of the issue are two very different essays, connected only by their focus on recent and current phenomena. The first is by Timothy Thurston of Leeds University and titled "A Careful Village: Comedic Dialogues and Linguistic Modernity in China's Tibet." It focuses on "a series of four comedic dialogues" that were popular in Tibet in the 1990s, in each of which "performances juxtapose urban sophisticates and country bumpkins in ways that allow comedians to grapple with questions of tradition and modernity in a rapidly modernizing society." This is followed by a piece by Aya H. Kimura, a sociologist at the University of Hawai'i at Manoa, which looks 
at the similarities and differences between two "types of program" that are both "filling a void left by the government" in responding to concerns about "food insecurity." Titled "Hungry in Japan: Food Insecurity and Ethical Citizenship," it draws attention to how "the failure of public safety nets" can inspire new kinds of private and voluntary enterprises in contemporary Japan.

\section{Forthcoming Articles in JAS 77.3 (August 2018)}

Research Articles

Memories of Korean Modernity: Yi Kwangsu’s The Heartless and New Perspectives in Colonial Alterity

Ellie ChOI

Do Korean-Japanese Historical Disputes Generate Rally Effects?

Wonjae Hwang, Wonbin Cho, and Krista Wiegand

Of Trees, a Son, and Kingship: Recovering an Ancient Chinese Dream

Edward L. Shaughnessy

What Is Mandarin? The Social Project of Language Standardization in Early Republican China

JEFFREY Weng

Seeing Cages: Home Confinement in Early Twentieth-Century Japan Yumi KIM

A Secular State for a Religious Nation: The Republic of Vietnam and Religious Nationalism, 1946-1963

Phi-VÂn NGuYeN

Brushing with Organized Crime and Democracy: The Art of Making Do in South Asia Lucia Michelutti, and Ashraf Hoque

Books without Borders: Phạm Thận Duật (1825-1885) and the Culture of Knowledge in Mid-Nineteenth-Century Vietnam

Kathlene BaLDanza 